DOI: $10.15290 /$ bsl.2018.13.13

\author{
Krzysztof Andruczyk \\ Wydział Filologiczny \\ Uniwersytet w Białymstoku \\ e-mail: andruczyk.krzysztof@gmail.com \\ ORCID: 0000-0003-3156-7117
}

\title{
Próba stworzenia nowego kanonu
}

Antologia ...czterdzieści i cztery. Figury literackie. Nowy kanon ${ }^{1}$ jest kolejnym projektem zrealizowanym przez zespół Archiwum Kobiet działający przy Instytucie Badań Literackich Polskiej Akademii Nauk pod kierownictwem Moniki Rudaś-Grodzkiej. Autorki i autorzy studiów zamieszczonych w obszernym, blisko siedemsetstronicowym tomie, podjęli się zreinterpretowania literackich figur kobiecych na stałe obecnych w zbiorowej wyobraźni Polaków, co przyczyniło się również do przedefiniowania pojęcia samej figury. Już spis treści monografii zwraca uwagę na jedną z jej najbardziej charakterystycznych cech - dużą rozpiętość tematyczną zamieszczonych esejów. Bohaterkami tomu są bowiem zarówno „charyzmatyczne” postaci literatury polskiej, takie jak Izabela Łęcka czy Jagna Borynowa, jak również figury nieoczywiste: Małpka Fiki-Miki czy upersonifikowany ocean otaczający planetę Solaris z powieści Stanisława Lema. To tylko niektóre przykłady, które przyjdzie jeszcze rozwinąć.

Spoiwem tak różnorodnych tematycznie tekstów stały się dwa kryteria badawcze, które legły u podstaw ogólnego zamysłu antologii. Pierwszym $\mathrm{z}$ nich jest figura mickiewiczowskiego "wybawiciela narodu”, enigmatycz-

\footnotetext{
1 ...czterdzieści i cztery. Figury literackie. Nowy kanon, red. M. Rudaś-Grodzka i in., Warszawa 2016.
} 
nego bohatera wspomnianego w widzeniu księdza Piotra w III części Dziadów. Jak we wstępie wskazują Monika Rudaś-Grodzka i Barbara Smoleń:

Najbardziej znana polska figura wyobraźni zbiorowej, postać „wskrzesiciela narodu", otoczona jest nimbem tajemniczości. Nikt nigdy nie dał w pełni wyczerpującej wykładni słynnego proroctwa księdza Piotra z Dziadów części III Adama Mickiewicza. Postać zamaskowanego zbawcy powraca w naszej kulturze nieustannie, przypomina się, ale nie daje do końca odczytać. Czeka na swój czas. Jej milczenie każe nam zastanawiać się, czy figura ta wskazuje tylko na siebie, czy także na coś jeszcze, na to, co do tej pory było niewidoczne, marginalne i ostatecznie nierozpoznane. Zmiana perspektywy pozwala wszakże dostrzec kształty innych figur. Tom ...czterdzieści i cztery. Figury literackie. Nowy kanon przedstawia czterdzieści i cztery postaci współtworzące - jak na to wskazuje magia mickiewiczowskiej cyfry - polską wyobraźnię. Rezygnujemy z kanonicznych odczytań, które raczej wzmacniają przesądy, uprzedzenia i stereotypy niż otwierają nowe, oryginalne ścieżki myślenia, odnawiania znaczeń, twórczego niepokoju. Uprawnienia do takiej lektury daje nam symbolika Mickiewiczowska, która nie jest wszakże jednoznaczna, zawiera element subwersywny i rewolucyjny - trzeba tylko umieć go zobaczyć².

Płynna, nierozstrzygalna tożsamość mickiewiczowskiego bohatera dla twórczyń monografii stała się rodzajem symbolicznego pretekstu, który pozwolił zwrócić uwagę na konstelacyjność zbiorowej wyobraźni Polaków kształtowanej, jak zakładają autorki, nie przez jedną postać, lecz wiele różnorodnych figur. Idea "czterdzieści i cztery” odzwierciedliła się tym samym w strukturze tomu, na który złożyło się tyleż studiów poświęconych postaciom zamieszkującym najróżniejsze terytoria narodowej wyobraźni.

Najważniejszym elementem łączącym prace zawarte $w$ książce nie jest jednak figura „wybawiciela narodu” znanego z dramatu Mickiewicza, lecz postaci inne, często - jak wskazują autorki wstępu - niedostrzegane, marginalizowane bądź niewystarczająco omówione, zarówno w kanonicznych, jak i najnowszych pracach literaturoznawczych. W centrum uwagi autorek i autorów studiów składających się na ...czterdzieści $i$ cztery znalazły się figury związane z kobiecością: główne, ale też drugoplanowe bohaterki polskiej literatury i kultury. Wartym odnotowania jest tutaj dobór analizowanego materiału: przedmiotem analiz badaczki uczyniły nie tylko figury literackie, lecz także postaci historyczne, również te o nie do końca jasnym pochodzeniu, jednak na stałe obecne w podświadomości Polaków. Tak określone zadanie badawcze wymagało przedefiniowania pojęcia figury literackiej, którą autorki wstępu ujmują jako:

\footnotetext{
2 Tamże, s. 11.
} 
postać historyczną lub fikcyjną, która w procesie zmian historycznych i społecznych nabrała znaczenia albo symbolicznego, albo alegorycznego, stając się podejmowanym i reinterpretowanym wciąż na nowo przez kolejne pokolenia wątkiem kulturowym znacząco wpływającym na konstrukcje tożsamościowe, uwikłane w kategorię płci kulturowej, także jako naród, wspólnota etniczna, klasa, rasa czy mniejszość seksualna ${ }^{3}$.

Zredefiniowanie pojęcia figury stało się również okazją do wyartykułowania badawczego credo, jakim dla pomysłodawczyń monografii jest z jednej strony objęcie uwagą postaci kanonicznych dla polskiej pamięci kulturowej, z drugiej zaś - co charakterystyczne dla badań feministycznych, ale również dla nowej humanistyki w ogóle - posłużenie się kategoriami obecnymi w badaniach postkolonialnych, postzależnościowych, modelującymi zarówno pojęcie samej figury, jak i zbiorowej tożsamości wspólnoty, w której wyobraźni owe figury funkcjonują. W dalszej części wstępu badaczki rozwijają przyjęte założenia o deklarację próby przełamania klasycznych odczytań wybranych postaci, a także - co wydaje się szczególnie interesujące - stawiają pytanie, skąd wzięły się normatywne, paradygmatyczne sądy na temat poszczególnych figur i dlaczego utrwaliły się w świadomości odbiorców polskiej kultury ${ }^{4}$.

Jak wskazują badaczki, inspiracją dla ogólnego zamysłu tomu oraz metodologii przyjętej $\mathrm{w}$ poszczególnych studiach, stały się prace Marii Janion, której tom ...czterdzieści i cztery jest też dedykowany. Patronat autorki Kobiet $i$ ducha inności zaznaczył się przede wszystkim w widocznym na kartach antologii przekonaniu o doniosłości figury jako elementu kształtującego zbiorową wyobraźnię, którego analiza może posłużyć głębszemu zrozumieniu kategorii określonej niegdyś przez Maurycego Mochnackiego jako „charakter narodowy" ${ }^{5}$. Inspiracje pracami Marii Janion można dostrzec także $\mathrm{w}$ indywidualnych badaniach prowadzonych przez redaktorki tomu, a zarazem uczennice i wychowanki twórczyni Goraczki romantycznej i Niesamowitej Słowiańszczyzny. Warto wspomnieć tu przede wszystkim o pracach Moniki Rudaś-Grodzkiej, autorki książek Sprawić, aby idee śpiewały oraz Sfinks słowiański i mumia polska. Jednym z głównych przedsięwzięć badawczych kierowniczki zespołu Archiwum Kobiet są dociekania na temat źródeł i specyfiki zbiorowej wyobraźni Polaków. ...czterdzieści i cztery nie jest więc książką powstałą "zz przypadku”, lecz wyrosłą z zainteresowań i zrealizowanych pro-

\footnotetext{
3 Tamże, s. 11-12.

4 Zob. tamże, s. 13.

5 Zob. M. Mochnacki, O duchu i źródłach poezji w Polszcze, w: tegoż, Rozprawy literackie, oprac. M. Strzyżewski, Wrocław 2004.
} 
jektów badawczych Rudaś-Grodzkiej oraz grona redaktorek tomu - Barbary Smoleń, Katarzyny Nadany-Sokołowskiej, Agnieszki Mrozik, Katarzyny Czeczot, Anny Nasiłowskiej, Ewy Serafin-Prusator, Agnieszki Wróbel - które na kartach antologii starały się kontynuować badania prowadzone przez Marię Janion.

Za centralną figurę narodowej wyobraźni, będącą również przedmiotem wnikliwych analiz autorki Niesamowitej Słowianszczyzny, badaczki uznały Polonię. Zdaniem autorek wstępu o ważnym miejscu, jakie w kulturze polskiej zajmuje owa figura, mają świadczyć jej przemiany odzwierciedlone na przestrzeni dziejów przede wszystkim w sztuce malarskiej. Polonia rozpoczyna więc swój żywot w XVI wieku, kiedy to wyobrażana jest jako matka bądź matka-dziewica, alegoria narodu będącego u szczytu gospodarczej i kulturowej potęgi, kształtującego zręby zbiorowej tożsamości. W okresie porozbiorowym, kiedy w sztuce (także literackiej) dominują tony melancholijne, w malarstwie Polonia ukazywana jest pod postacią ciała kobiety składanej do grobu. W okresie XIX-wiecznych zrywów niepodległościowych „centralna figura wyobraźni polskiej" ulega drastycznej przemianie, do obrazów Polonii wkradła się frenezja, a ją samą przedstawiano jako kobietę maltretowaną przez oprawców narodu polskiego. Ostatni zwrot w wyobrażeniu figury ma miejsce $\mathrm{w}$ okresie pierwszej wojny światowej, kiedy to martyrologiczno-tyrtejski wizerunek alegorycznej Polski został zastąpiony przez obraz kobiety radosnej, witalnej, której nieodłącznym atrybutem była - w przypadku niektórych artystycznych reprezentacji również prowokacyjna - nagość 6 . Wychodząc od przemian w wizerunku Polonii, autorzy i autorki studiów składających się na ...czterdzieści i cztery poświęcili uwagę kilkudziesięciu figurom kobiet współtworzącym i odzwierciedlającym polską tożsamość.

Jak już zostało wspomniane, studia opublikowane w recenzowanej antologii cechują się ogromną różnorodnością. Objętościowe ograniczenia niniejszego tekstu uniemożliwiają mi omówienie wszystkich rozdziałów tej obszernej pracy, warto jednak przyjrzeć się książce jako całości realizującej przynajmniej niektóre pomysły badawcze, które przyświecały powstaniu ...czterdziestu $i$ czterech. W pierwszej kolejności wypada więc powiedzieć o tym, kim są bohaterki monografii.

Postaci, które znalazły się w centrum zainteresowań autorów i autorek studiów zamieszczonych $\mathrm{w}$ antologii można, przy zastosowaniu uproszczonego klucza, podzielić na trzy grupy:

\footnotetext{
6 ...czterdzieści i cztery..., s. 12-13. Zob. również M. Janion, Niesamowita Słowiańszczyzna. Fantazmaty literatury, Kraków 2006.
} 
I. Postaci znane z lektur szkolnych i kanonicznych dzieł literatury polskiej.

II. Postaci historyczne, które otrzymały drugie, często równie intensywne jak biologiczne, życie w przestrzeni kultury.

III. Postaci o zwielokrotnionej tożsamości, nieposiadające konkretnego odpowiednika literackiego bądź historycznego, jednak silnie obecne w (pod)świadomości Polaków.

Pierwszą grupę tworzą zarówno postaci znane z lektur szkolnych - Balladyna, Róża Żabczyńska, Dulska, Horpyna Dońcówna, Jagna, Karusia, Izabela Łęcka, Ligia, Sierotka Marysia, Stasia Bozowska (Siłaczka), Telimena, Urszula Kochanowska, Zosia (bohaterka Pana Tadeusza) i Zuta Młodziakówna - jak również bohaterki z (czasem „mniej znanej”) klasyki literatury polskiej: Aspazja, Aza, Biała Róża, Bianka, Ewa Pobratyńska, Halka, Hela Bertz, Madzia Brzeska i inne. Postaci te, w znakomitej większości znane także mniej wyrobionym czytelnikom, często wiele tracą $\mathrm{w}$ wyniku utrwalenia ich „szkolnych" wizerunków w powszechnym odbiorze. Jak słusznie zauważa Anna Nasiłowska - autorka studium poświęconego mickiewiczowskiej Telimenie - stereotypizacja wizerunku bohaterek kanonicznej literatury polskiej widoczna jest przede wszystkim w tematach szkolnych wypracowań. Tego rodzaju tematy, których wzory można odnaleźć w podstawie programowej, to często quasi-komparatystyczne rozprawki dotyczące porównania skrajnie różnych postaci (różnych zarówno pod względem charakteru, jak i wieku czy podejścia do życia). Choć celem tego rodzaju prac ma być stworzenie zrębu charakterystyki bohaterów i bohaterek literackich, wpływają one, jak wskazała Nasiłowska, na daleko idącą banalizację ich wizerunków w powszechnej świadomości. Sprowadzają się bowiem zwykle do uwypuklenia negatywnych cech jednej postaci przy jednoczesnym gloryfikującym uwzniośleniu cech drugiej (przykładowo złej Balladyny i dobrej Aliny, rozwiązłej i leniwej Jagny oraz pracowitej i skromnej Hanki). W tekstach składających się na ...czterdzieści $i$ cztery wyraźnie widać zdecydowane odejście od tego rodzaju odczytań, nierzadko obecnych także w tekstach naukowych.

Tendencja reinterpretacyjna widoczna jest $w$ niemalże wszystkich studiach poświęconych kanonicznym postaciom literatury polskiej. Badaczki i badacze konsekwentnie unikają interpretacji, które mogłyby zostać uznane za "typowe" dla danej postaci, czego przykładem może być wspomniany już tekst Nasiłowskiej, polemizującej z nieprzychylnymi (z reguły) wobec Telimeny sądami historyków literatury. Badaczka wskazuje przy tym znaczące puste miejsca Mickiewiczowskiego poematu, w którym brakuje jednoznacznych informacji na temat pochodzenia bohaterki (zapewne więc nie-rodzimego) czy jej statusu w soplicowskiej społeczności, a wszystko to 
sprawia, że Telimena staje się Mickiewiczowskim „wieszakiem na atrybuty” kobiecości ${ }^{7}$. Duch reinterpretacyjny przenika także esej Barbary Smoleń o Jagnie, bohaterce Chłopów Władysława Reymonta. W swoim artykule badaczka podejmuje dyskusję z nieco szkolną w swej wymowie pracą Jadwigi Zacharskiej, która skupiła się na analizie najodpowiedniejszego wizerunku gospodyni wiejskiej w Chłopach Reymonta, zestawiając ze sobą Hankę i Jagnę8. Wbrew obiegowym interpretacjom, w eseju Barbary Smoleń Jagna nie stała się postacią podporządkowaną wyłącznie własnej biologii, ale została pokazana jako inna/obca, która swoim zachowaniem dąży do przełamania patriarchalnych zasad rządzących wiejską społecznością.

Nowe spojrzenie na znane figury literackie widoczne jest również w metodologicznym podejściu autorek i autorów studiów do literatury. Na kartach antologii próżno szukać tak zwanego tradycyjnego literaturoznawstwa skupionego na analizach o strukturalistycznej proweniencji. Autorki i autorzy tomu zdecydowanie częściej sięgają po narzędzia badawcze wypracowane na gruncie nowej humanistyki, a więc przede wszystkim krytyki feministycznej, gender i queer studies oraz po krytykę kolonialną. Już w tym miejscu można stwierdzić, że dobór metodologii okazał się bardzo trafny i produktywny. $\mathrm{W}$...czterdzieści i cztery nowe narzędzia badawcze nie przesłaniają bowiem historycznego kontekstu epoki, w której tworzono dzieła będące obiektem analiz, otwierają natomiast możliwości innego spojrzenia na dobrze znane w kulturze figury oraz na doczytanie najbardziej zaniedbanych przestrzeni literatury polskiej.

Podejście metodologiczne twórczyń i twórców monografii, deklarowane również $\mathrm{w}$ cytowanym wcześniej wstępie, legło u podstaw chyba najistotniejszej dominanty tematycznej antologii - kobiety jako Innego/Obcego. Jak pisze Bernhard Waldenfels: „Na obrzeżach każdego porządku wyłania się obce $\mathrm{w}$ postaci czegoś nadzwyczajnego, na co $\mathrm{w}$ danym porządku nie ma miejsca, co jednak - jako to, co wykluczone - nie jest niczym" ${ }^{\prime}$. Teza sformułowana przez autora Podstawowych motywów fenomenologii obcego odzwierciedla się wyraźnie na kartach tomu ...czterdzieści $i$ cztery. Niemal wszystkie analizowane $\mathrm{w}$ tomie figury kobiet/kobiecości są jednocześnie realizacją Innego/Obcego wypartego przez społeczność na jej obrzeża. Bohaterki

\footnotetext{
7 Tamże, s. 594.

8 Zob. J. Zacharska, Hanka czy Jagna? Ideat kobiety wiejskiej, w: tejże, O kobiecie w literaturze przełomu XIX i XX wieku, Białystok 2000 [por. ...czterdzieści i cztery..., s. 253-263].

9 B. Waldenfels, Podstawowe motywy fenomenologii obcego, przeł. J. Sidorek, Warszawa 2009, s. 5 .
} 
tomu w przeważającej mierze funkcjonują jako realizacje freudowskiej kategorii das Unheimliche, "wyparte” z centrum swojego środowiska, powracają, by rozbijać dotychczasowy porządek, nierzadko przypłacając to własną klęską. Znaczna grupa bohaterek pojawiających się na kartach tomu to postaci sprawcze, naznaczone potrzebą przekraczania własnej płci, pochodzenia czy statusu społecznego. Kategoria inności jest przypisywana bohaterkom nie tylko ze względu na ich płeć, ale również przez próby łamania patriarchalnego porządku. Do tej grupy postaci zalicza się nie tylko wspomniana wcześniej Jagna, ale również między innymi Bela Hertz z Pożegnania jesieni Witkacego, Horpyna Dońcówna czy też Balladyna, bohaterka znakomitego eseju Michała Kuziaka. Przedstawiane są one jako postaci wielowymiarowe, poprzez swoje zachowanie uczestniczące $\mathrm{w}$ zawiłym performansie płci i prowadzące skomplikowaną grę ze światem rządzonym przez mężczyzn.

Znaczną grupę bohaterek książki współtworzą również postaci, które nie dążą do sprawstwa w otaczającym je świecie, ale chcą jedynie odnaleźć w nim przestrzeń dla własnej egzystencji. Niezmiennie są jednak odrzucane przez swą inność czy też niemożność przystosowania się do nieprzychylnej im rzeczywistości. W tej grupie odnaleźć można zarówno figury literackie (jak Aza, cygańska bohaterka Chaty za wsia Ignacego Kraszewskiego, naznaczona piętnem inności nie tylko z uwagi na swoją płeć, ale również pochodzenie), jak i postaci historyczne. Wśród reprezentantów tej grupy uwagę zwraca przede wszystkim studium Karoliny Krasuskiej poświęcone Marii Komornickiej/Piotrowi Odmieńcowi Włastowi. Badaczka przedstawia Komornicką/Własta jako postać tragiczną, której usilne próby przekroczenia własnej płci zakończyły się posądzeniem o chorobę psychiczną i umieszczeniem w ośrodku dla umysłowo chorych, gdzie przyszło jej/jemu spędzić znaczną część życia. Postaci historyczne stanowią nieliczną, ale niezwykle interesującą reprezentację bohaterek antologii. Oprócz Komornickiej w książce znaleźć można eseje poświęcone Barbarze Radziwiłłównie, Poli Raksie czy Gertrudzie Komorowskiej. Życiorysy tych postaci niejednokrotnie stawały się źródłem inspiracji dla twórców popularnych filmów, które przyczyniły się do utrwalenia ich wizerunków w zbiorowej świadomości.

Najbardziej interesującą grupę reprezentują bohaterki o zwielokrotnionej tożsamości, nieposiadające konkretnego prototypu ani w literaturze i sztuce, ani w rzeczywistości historycznej. Do takich postaci można zaliczyć Helę Traktorzystkę, bohaterkę powieści dla młodzieży autorstwa Marty Michalskiej. Wychodząc od przywołania figury literackiej, Agnieszka Mrozik (autorka eseju zatytułowanego Hela Traktorzystka) przygląda się kulturowym konotacjom profesji traktorzystki - popularnej w Związku Radzieckim oraz 
w powojennej Polsce. Innym przykładem jest znakomity esej Marty Taperek zatytułowany Natalia w Brooklynie. Tytułowa figura eseju, pierwotnie bohaterka rockowej piosenki autorstwa Kazika Staszewskiego, staje się okazją dla rozważenia kulturowego wizerunku Polki na emigracji oraz ukazaniu przemian obrazu wychodźstwa w literaturze i filmie. Badaczka dąży tym samym do zdekonstruowania pokutującego w polskiej kulturze wyobrażenia emigranta jako mężczyzny opuszczającego ojczyznę z powodów politycznych, nieumiejącego odnaleźć się $\mathrm{w}$ nowej rzeczywistości, trawionego rozpaczliwą tęsknotą za porzuconym krajem. Taperek poddaje analizie różne typy emigrantek, poczynając od figury kobiety migrującej „za pracą” lub ukochaną osobą ${ }^{10}$, a kończąc na bohaterkach, dla których emigracja, mimo separacji od ojczyzny i rodziny, staje się jedyną szansą na zrealizowanie marzeń o wolności.

Esej Marty Taperek - w moim odczuciu jeden $\mathrm{z}$ najlepszych, obok pracy Michała Kuziaka o Balladynie, tekstów zamieszczonych w ...czterdzieści i cztery - ilustruje inną, niewątpliwie ważną, acz niewyartykułowaną we wstępie cechę monografii: odniesienie tradycyjnej figury do współczesnych zjawisk popkulturowych. Znakomita większość autorek i autorów analiz zamieszczonych $w$ tomie nie poprzestaje na rozważaniach o odbiorze danej figury $\mathrm{w}$ jej macierzystym okresie historycznym, ale poszerza je o recepcję omawianej postaci $\mathrm{w}$ najnowszej kulturze, także kulturze popularnej, która, jak wiadomo, jest obecnie najlepszym recypientem szeroko pojętej tradycji. Przedmiotem eseju Marty Taperek, prezentującego szerokie ujęcie analizowanego tematu, stały się więc nie tylko emigrantki znane z tak zwanej wysokiej literatury, ale również bohaterki amerykańskich seriali: Gossip Girl oraz Broke Girls. Badaczka skupia uwage na analizie wizerunku drugoplanowych postaci obu seriali, którymi są polskie sprzątaczki. Analiza wytworów popkultury staje się tu zarówno okazją dla ukazania mniej znanego wizerunku kulturowego Polki-emigrantki, jak również daje możliwość "odwrotnego" spojrzenia na polską kulturę i postawienia pytania: jak nas widzą inni. Dzięki zwróceniu uwagi na figury emigrantek pojawiających się nie tylko w kanonicznych dziełach polskiej literatury, ale również $\mathrm{w}$ utworach popkulturowych, takich jak serial czy rockowa piosenka, badaczce udało się przedstawić wielowymiarowy obraz oraz ewolucję analizowanej postaci.

${ }^{10}$ Jak dowodzi badaczka, tego rodzaju postawa w polskiej literaturze spotykała się zwykle z naganą ze strony autorów „emigracyjnych" powieści i opowiadań, czego przykładem może być Ewa Pobratyńska z Dziejów grzechu Stefana Żeromskiego [s. 484]. 
W przypadku eseju Marty Taperek odwołania do popkultury są naturalną drogą analizy figury, która stanowi nieodłączny element nowoczesnej tożsamości Polaków tworzących, jak wiadomo, bardzo liczną diasporę na całym świecie. W inny sposób do kultury popularnej nawiązuje z kolei Michał Kuziak we wspomnianym już eseju o Balladynie. W pierwszej kolejności badacz przedstawił wieloaspektową analizę bohaterki Słowackiego, w której odwołał się zarówno do postrzegania kobiety w romantyzmie, jak i do frapującej konstrukcji dzieła Słowackiego - połączenia dramatu mitycznego (kroniki historycznej) oraz dramatu ironicznego. W swoich analizach Kuziak nie mniejszy nacisk położył również na kwestię funkcjonowania bohaterki w patriarchalnym świecie dramatu oraz na swoistą grę, jaką z owym światem prowadzi Balladyna. Kolejne odczytanie dramatu autora Beniowskiego, odznaczającego się, jak wiadomo, niezwykle kunsztowną warstwą intertekstualną, wielowymiarową grą prowadzoną z tradycją oraz charakterystyczną dla ironii romantycznej (ale wszakże również dla "nieromantycznego" postmodernizmu) dekonstrukcją ontologii świata przedstawionego, stało się również okazją do spojrzenia na przyszłe losy Balladyny. Badacz w znakomity sposób uzupełnił swoje wielowątkowe analizy przywołaniem dzieł literackich będących ilustracją „pośmiertnego" życia Balladyny: utrzymanej w duchu historycznej fantasy powieści Sławomira Mrugowskiego Dziedzictwo krwi oraz postmodernistycznej wizji tradycji zobrazowanej w Balladynach i romansach Ignacego Karpowicza. Oba teksty stanowią różną, nie zawsze zgodną z dotychczasowym obrazem dramatu Słowackiego, próbę rozwinięcia losów bohaterki. Uważniejsze przyjrzenie się wspomnianym utworom pokazuje, iż figury wywodzące się z dawno kanonizowanych dzieł literackich mogą odnaleźć dla siebie miejsce także w najnowszej kulturze, stając się nośnikami reinterpretacji tradycji oraz ukazując przemiany zbiorowej wyobraźni odbiorców i twórców kultury.

Przedstawienie łączności tradycji z kulturą najnowszą jest jedną z największych zalet antologii ...czterdzieśsi i cztery. Autorki i autorzy studiów zamieszczonych $\mathrm{w}$ tomie udowadniają tym samym potrzebę prowadzenia badań historycznoliterackich opartych nie tylko na pracy archiwistycznej, ale przede wszystkim na analizie wpływu, jaki tradycja wywiera na zbiorową wyobraźnię i tożsamość współczesnych jej odbiorców. Tego rodzaju podejście widoczne jest również $\mathrm{w}$ analizach dzieł na poły zapomnianych, funkcjonujących na obrzeżach kanonu. Każda analiza utworu, który dziś może być postrzegany jako - by raz jeszcze przywołać tytuł serii wydawnictwa Universitas - „klasyka mniej znana”, koresponduje nie tylko z najnowszą kulturą, ale też z takimi problemami współczesnego świata, jak rasizm (wybrzmiewający między innymi $\mathrm{w}$ analizie Chaty za wsia Kraszewskiego 
autorstwa Kazimiery Szczuki) czy emancypacja kobiet, której najróżniejsze oblicza zostały przedstawione $\mathrm{w}$ niemal wszystkich zamieszczonych $\mathrm{w}$ tomie esejach.

Studia współtworzące antologię ...czterdzieści i cztery nie stanowią jednak wyłącznie próby zilustrowania recepcji kanonicznych figur literackich i ich znaczenia dla współczesnej wyobraźni - choć jest to niewątpliwie największy atut tomu. Poszczególne analizy odznaczają się przede wszystkim walorem wieloaspektowego spojrzenia na daną postać literacką lub historyczną. Tak jak we wstępie książki zaznaczyły Monika Rudaś-Grodzka i Barbara Smoleń, autorki i autorzy studiów zrezygnowali z klasycznych odczytań analizowanych tematów. Na kartach ...czterdzieści i cztery próżno więc szukać anachronicznych z perspektywy nowej humanistyki analiz symboli czy tropów literackich oraz wciąż pokutującego we współczesnej humanistyce esencjalistycznego spojrzenia na dzieło literackie. Kanon, sugerowany $\mathrm{w}$ podtytule tomu ...czterdzieści i cztery, nie jest więc dany i trwały, powstaje $\mathrm{w}$ toku recepcji, wraz nawarstwianiem się pamięci kulturowej, jej monitorowaniem i przewartościowaniami, czemu służą między innymi reinterpretacje tworzących ją tekstów. Poszczególne eseje stanowią więc przede wszystkim próbę możliwie najszerszego spojrzenia na figury kobiece $\mathrm{w}$ literaturze polskiej ostatnich stuleci. Ponieważ badaczki i badacze skupili się na przedstawieniu recepcji analizowanych postaci na tle przemian kulturowych Polski i Europy, w poszczególnych esejach nie brak cennych prób komparatystycznych - jak np. w niezwykle interesującym studium Leny Magnone poświęconym spojrzeniu na Ewę Pobratyńską z Dziejów grzechu Żeromskiego jako na daleką krewną Justyny, bohaterki powieści Markiza de Sade Justyna, czyli niedole cnoty. Próby usytuowania poszczególnych figur w przestrzeni kultury europejskiej i światowej dowodzi dialogicznego charakteru analizowanych postaci, które stanowią ilustrację nie tylko polskiej wyobraźni narodowej, ale są również nieodłączną częścią kultury w ogóle.

Walorem antologii jest również dążenie jej twórców do przywrócenia pamięci o postaciach mniej znanych, niejednokrotnie zupełnie zapomnianych. Autorki i autorzy esejów spoglądają tym samym na literaturę polską z innej, często marginalizowanej perspektywy. Recenzowana książka wpisuje się tym samym w ważny nurt badań feministycznych realizowanych w Polsce z powodzeniem przez badaczki tworzące zespół Archiwum Kobiet. Z badaniami feministycznymi bowiem wiąże się pytanie o najważniejsze zadanie, jakie postawili przed sobą autorki i autorzy tomu, a więc wybrzmiewającą już w tytule monografii deklarację stworzenia nowego kanonu. Aby odpowiedzieć na pytanie, czy bohaterki tomu ...czterdzieści i cztery stały się również współtwórczyniami nowego, niemęskocentrycznego kanonu literatury 
polskiej, potrzeba będzie czasu. Jednak niewątpliwie monografia ...czterdzieści $i$ cztery jest jednym $\mathrm{z}$ najważniejszych głosów $\mathrm{w}$ debacie ${ }^{11}$ o stworzeniu nowego kanonu literatury polskiej.

Monografię ...czterdzieści i cztery. Figury literackie. Nowy kanon wypada więc ocenić jako niezwykle wartościową i interesującą próbę nowego spojrzenia zarówno na figury składające się na tożsamość kulturową Polaków, jak również na kulturę polską w ogóle. Recenzowany leksykon będzie cenną pozycją nie tylko dla odbiorców tekstów naukowych, ale też dla uczniów i nauczycieli szkół średnich, przede wszystkim zaś dla twórców podstawy programowej, którzy mogliby dostrzec potrzebę uważniejszego przyjrzenia się kanonicznym figurom polskiej kultury i wyzwolenia ich od upiora banalizacji straszącego w tytułach wypracowań szkolnych czy tematów maturalnych. Pozostaje mieć nadzieję, że monografia ...czterdzieści i cztery nie jest jedyną tego typu inicjatywą. Jako czytelnik byłbym zainteresowany zaprezentowaniem drugiego bieguna nowego kanonu, a więc stworzenia analogicznego leksykonu figur związanych z męskością ukazanych w podobnym reinterpretacyjnym duchu. Stworzenie tego rodzaju monografii byłoby kolejnym krokiem do wciąż niezwykle potrzebnego, odświeżonego spojrzenia na literaturę polską.

\section{Bibliografia}

Janion Maria (2006), Niesamowita Stowiańszczyzna. Fantazmaty literatury, Kraków: Wydawnictwo Literackie.

Kontowski Daniel (2014), Kanon literacki a liberal education: społeczny sens pewnej debaty, w: Polonistyka dziś - kształcenie dla jutra, t. 1, red. K. Biedrzycki i in., Kraków: Universitas.

Kowalski Piotr (2004), Popkultura i humaniści, Kraków: Wydawnictwo Uniwersytetu Jagiellońskiego.

Mochnacki Maurycy (2004), O duchu i źródłach poezji w Polszcze, w: M. Mochnacki, Rozprawy literackie, oprac. M. Strzyżewski, Wrocław: Ossolineum.

Rudaś-Grodzka Monika i in. [red.] (2016) ...czterdzieści i cztery. Figury literackie. Nowy kanon, Warszawa: Wydawnictwo Instytutu Badań Literackich PAN.

Waldenfels Bernhard (2009), Podstawowe motywy fenomenologii obcego, przeł. J. Sidorek, Warszawa: Oficyna Naukowa.

11 Zob. m.in., D. Kontowski, Kanon literacki a liberal education: społeczny sens pewnej debaty, w: Polonistyka dziś - ksztatcenie dla jutra, t. 1, red. K. Biedrzycki i in., Kraków 2014; P. Kowalski, Popkultura i humaniści, Kraków 2004; Europejski kanon literacki. Dylematy XXI wieku, red. E. Wichrowska, Warszawa 2012. 
Wichrowska Elżbieta [red.] (2012), Europejski kanon literacki. Dylematy XXI wieku, Warszawa: Wydawnictwa Uniwersytetu Warszawskiego.

Zacharska Jadwiga (2000), Hanka czy Jagna? Ideat kobiety wiejskiej, w: J. Zacharska, O kobiecie w literaturze przetomu XIX i XX wieku, Białystok: Wydawnictwo Uniwersytetu w Białymstoku.

\title{
The Attempt at the New Canon
}

\begin{abstract}
The article discusses the anthology ...czterdzieści i cztery. Figury literackie. Nowy kanon (Warsaw 2016) dedicated to the literary figures of women who contributed to the formation of collective imagination. One of the great assets of the reviewed volume published by Women Archive at the Institute of Literary Research of the Polish Academy of Sciences is the modern methodology. The research tools from such fields as feminist critique, gender and queer studies as well as postcolonial criticism do not obliterate historical context of the analyzed works but they offer the opportunities for fresh readings of literary figures and the previously neglected literary space. Consequently, the discussed anthology succeeds in redefining Polish literary canon.
\end{abstract}

Keywords: literary canon, literary criticism, reinterpretation, feminism, postcolonialism 